The (Un-) importance of Chapter 7 wealth exemption levels

Jochen Mankart

September 2013 Discussion Paper no. 2012-11 


$\begin{array}{ll}\text { Editor: } & \text { Martina Flockerzi } \\ & \text { University of St.Gallen } \\ & \text { School of Economics and Political Science } \\ & \text { Department of Economics } \\ & \text { Varnbüelstrasse 19 } \\ & \text { CH-9000 St. Gallen } \\ & \text { Phone } \quad+41712242325 \\ & \text { Fax } \quad+41712243135 \\ & \text { Email seps@unisg.ch } \\ & \text { School of Economics and Political Science } \\ & \text { Department of Economics } \\ & \text { University of St.Gallen } \\ & \text { Varnbüelstrasse } 19 \\ \text { Publisher: } & \text { CH-9000 St. Gallen } \\ & \text { Phone +41 71 224 23 25 } \\ & \text { Fax +41 71 224 31 35 } \\ & \text { http://www.seps.unisg.ch }\end{array}$




\title{
The (Un-) importance of Chapter 7 wealth exemption levels ${ }^{1}$
}

\author{
Jochen Mankart
}

Author's address:

Jochen Mankart, $\mathrm{PhD}$

Institute of Economics (FGN-HSG)

Varnbüelstrasse 19

$\mathrm{CH}-9000$ St. Gallen

Phone +4171 2242155

Fax +41712242874

Email jochen.mankart@unisg.ch

Website www.mankart.net

\footnotetext{
${ }^{1}$ I am grateful to Francesco Caselli, Wouter denHaan, Christian Keuschnigg, Winfried Koeniger, Xavier Mateos-Planas, Alex Michaelides, Giacomo Rodano and seminar participants at the University of St. Gallen and the Royal Economic Society meeting for helpful comments. All remaining errors are mine. Finanical support of the Profilbereich Wirtschaftspolitik at the University St. Gallen is gratefully acknowledged. An earlier version was part of my PhD thesis.
} 


\begin{abstract}
This paper examines the effects of the Chapter 7 wealth exemption level on welfare, bankruptcy filings, debt, and on asset holdings. I build a heterogeneous agent life cycle model which features uninsurable income and expense shocks. Moreover, households can borrow and save simultaneously. When a borrower defaults on her debt by filing for Chapter 7 bankruptcy, she can keep her assets up to the wealth exemption level. Wealth exemption levels are important for two reasons. First, they explain the extensive and intensive margin of the credit card debt puzzle identified by Gross and Souleles (2002b). Around thirty percent of borrowers, both in the model and in the data, who borrow at high interest rates simultaneously save at low interest rates. However, these borrowers borrow and save only relatively small amounts, a few thousand U.S. Dollars. Second, ignoring the exemption level biases results because it overstates the costs of defaulting. The welfare gains from Chapter 7 compared to the European system, where debt is not discharged, are twice as high when exemption levels are positive compared to when they are ignored. At the same time, wealth exemption levels are unimportant in the sense that they have an impact only at low exemption levels. The effects of increases in the exemption level fade out very quickly. There is no strong positive relationship between exemption levels, which vary across U.S. states, and default rates in the model. This is in contrast to the previous literature, but consistent with the data. The reason is that those borrowers who might default do not own much wealth. Therefore, only very few households are affected by increases in the exemption level.
\end{abstract}

\title{
Keywords
}

Personal bankruptcy law, wealth exemption level, asset portfolios, credit card debt puzzle.

\section{JEL Classification}

E21, D31, K35. 


\section{Introduction}

The steep increase in consumer bankruptcy filings in the 1990ies and early 2000s led to an increased interest in the workings of personal bankruptcy laws. On the one hand, there has been a public debate leading to a reform of the US bankruptcy law. On the other hand, there has been a growing interest among economists in models that are able to explain observed behavior and that can be used to evaluate different bankruptcy policies.

In order to investigate the effects of changing the exemption level, I extend the heterogeneous agent life cycle model by Livshits, MacGee, and Tertilt (2007) by allowing borrowers to simultaneously save. In addition to facing uncertainty over their labor income, agents also face wealth shocks that stem from unexpected changes in family composition or from unexpected medical expenses. These are the most important reasons for bankruptcies (Sullivan, Warren, and Westbrook, 2000) in the US. The model features incomplete financial markets. I allow for two assets only: unsecured debt and savings. The possibility to default then introduces some contingency and therefore moves the financial system closer to complete markets. ${ }^{1}$ This default option gives consumers insurance against the economic consequences of the shocks to their income or wealth. The model yields three important results.

First, it can explain the credit card debt puzzle. This puzzle was documented by Gross and Souleles (2002b). They show that about one third of households who borrow on their credit cards have liquid assets in excess of one month wage income. The median credit card interest rate in their period was $16 \%$ while the rate on checking accounts was $1-2 \%$. In the model, one third of households who borrow at high interest rates save simultaneously at a low interest rate. Moreover, the model replicates the joint distribution over assets and debt that is observed in the Survey of Consumer Finances rather well. The median debt holdings of the credit card debt puzzle group are $\$ 2,800$ in the data and $\$ 2,500$ in the model while their median asset holdings are $\$ 7,000$ in the data and $\$ 6,200$ in the model.

Second, the exemption level is important because it can explain the credit card debt puzzle and because ignoring it can lead to biased results. My model nests Livshits et al. (2007) in which borrowers cannot save. In their calibration only $7 \%$ of defaulters have experienced no expense shock, i.e. are due to income shocks only. In the calibration with a positive exemption level, this fraction more than doubles to $18 \%$ which is more in line with survey evidence showing that expense shocks and income shocks are about equally important. Moreover, the welfare gains from moving from a European style system, in which debt is not discharged upon default, to Chapter 7 double from $0.06 \%$ to $0.12 \%$ of the annual consumption equivalent.

Third, the exemption level differs a lot across US states, ranging from a few thousand US dollars in Maryland to an unlimited amount in Florida. Higher exemption levels increase the incentive to default. Therefore, one would expect to see a positive relationship between the exemption level and default rates, unless credit rationing becomes so severe that many households are excluded from borrowing altogether. A strong positive relationship is predicted by previous papers that investigated the optimal exemption level of Chapter 7 consumer bankruptcy code, see for example Athreya (2006), Pavan (2008) or Lopes (2008).

\footnotetext{
${ }^{1}$ For a theoretical evaluation of that trade-off see Dubey, Geanakoplos, and Shubik (2005).
} 
However, there is no significant relationship between the exemption level and bankruptcy filings in the data. Even though my model features a positive relationship between the exemption level and bankruptcy rates, the effect is very small, in particular for exemption levels above a relatively modest value of $\$ 10,000$. My quantitative evaluations show that the welfare difference between low and high exemption levels are rather small, less than $0.1 \%$ of annual consumption. This might explain why the differences in the exemption level across US states have not disappeared over time.

All variables of interest follow a similar pattern as the bankruptcy rate. There are significant changes when the exemption is increased from zero to a small positive level. However, increases beyond an intermediate exemption level do not lead to any significant further changes. The reason for this is that those households who borrow and who might default are relatively poor and hold at most a small amount of assets. This is consistent with records on Chapter 7 cases. Lenders recover nothing in more than $95 \%$ of these cases.

The quantitative literature on consumer bankruptcy has increased a lot since Athreya's original paper in 2002. He found that eliminating the default option would be welfare increasing. Chatterjee, Corbae, Nakajima, and Rios-Rull (2007) show that the recent tightening of the law in the US implies large welfare gains. Livshits et al. (2007) compare the US system with a much harsher European type of system. In the former future earnings cannot be garnished while in the latter future earnings are garnished to repay creditors. They find that the welfare differences between the systems depend on the persistence and variance of the shocks. Pavan (2008) and Hintermaier and Koeniger (2011) extend the standard one-good model by including both durable and non-durable goods in the model. Hintermaier and Koeniger (2011), in contrast to Pavan (2008) but consistent with my model, find that the exemption level does not matter much for the default rate.

My modeling of the asset market is close to Li and Sarte (2006) who also have both, unsecured debt and savings. Their model, however, uses an infinite horizon framework with the only uncertainty coming from changes in labor productivity. This is also the case in Athreya (2006) who investigates the optimal exemption level in a model with secured and unsecured debt. Both, life cycle issues and wealth shocks however are important for the welfare results. Moreover, debt in their models is not priced according to individual household's risk characteristics. This is also the case in Lopes (2008) who addresses the credit card debt puzzle. In all these papers, there is pooling in the credit market which is in contrast to the data, as shown by Edelberg (2006). This makes their results difficult to interpret. For example, the cross subsidization in Lopes (2008) leads to an age profile of defaulters that is the opposite of the data. ${ }^{2}$ In her model, it is the old and young who borrow unsecured and default. Under risk-based pricing these groups face far higher interest rates. This lowers their borrowing and hence they default less often. This is exactly what happens in my model. This leads to the hump-shaped pattern in the default rate over the life cycle that we also observe in the data.

My finding that the exemption level hardly matters for bankruptcy rates is consistent with Lefgren and McIntyre (2009). They show that cross state differences in bankruptcy rates are mainly affected by differences in garnishment restrictions, non legislated legal institutions, and demographic factors. The exemption level, in contrast, has only a

\footnotetext{
${ }^{2}$ See Figure 8.
} 
minor impact. This is also true for Fay, Hurst, and White (2002). They find a positive effect of the financial benefit from default which is defined as debt-nonexempt assets. But this result is entirely driven by debt and not by assets which are insignificant in a separate regression.

The credit card debt puzzle has recently been addressed by Bertaut, Haliassos, and Reiter (2009) and by Telyukova (2013). Bertaut et al. (2009) explain the credit card debt puzzle by a self control problem in an 'accountant-shopper' framework. The accountant and the shopper could be two persons in a household or one person with time inconsistent preferences. The shopper has a lower discount factor and therefore consumes more than the accountant would like him to do. The accountant anticipates this and limits the spending of the shopper by not paying off all credit card debt so that the shopper does not spend that much. Instead the accountant saves in a liquid asset. A key friction in this model is the assumption that the shopper, while having access to the credit card, does not have access to the liquid assets. This assumption seems questionable given that almost all households who have credit cards also have debit cards.

Telyukova (2013), building on Telyukova and Wright (2008), explains the puzzle by liquidity needs. She demonstrates that certain expenditures cannot be paid for by credit cards but have to be paid by liquid assets. She develops a quantitative model which includes a cash only market which can replicate the credit card debt puzzle. A key friction in that model, in effect the mirror image of the friction in Bertaut et al. (2009), is a strict cash in advance constraint in the cash only market. This assumption seems questionable as well since cash advances on credit cards are feasible. It is unclear whether a model without a strict cash in advance constraint but a realistic cost function for cash advances would still be able to explain the credit card debt puzzle. However, the liquidity explanation is certainly plausible for low amounts of liquid asset holdings. Since I do not have a liquidity motive in my model, I follow Gross and Souleles (2002b) and consider only those households as puzzle households who hold liquid assets in excess of their monthly net income.

In both of these models, credit card debt is risk free. However, in section 2 I show that the credit card interest rates, which the puzzle households have to pay, include a significant default premium. In fact, this default premium is almost as high as for households who only borrow and much higher than the one for households who only save. Thus empirically, the default risk is a major feature in the price which these households face for their borrowing.

This paper is structured as follows. Section 2 explains the US bankruptcy code and shows the credit card debt puzzle in the data. Section 3 lays out the model. Section 4 discusses the benchmark calibration and the main mechanisms of the model, and shows the credit card debt puzzle in the model. Section 5 examines the impact of changing the exemption level on default rates, default reasons, borrowing and savings decisions, and on welfare. Section 6 concludes. The appendix includes the computational algorithm and more detailed results for the alternative calibration. 


\section{Consumer bankruptcy and credit card debt puzzle}

Personal bankruptcy law in the US consist of two different procedures: Chapter 7 and Chapter 13. Under Chapter 7, all unsecured debt is discharged immediately, and future earnings cannot be garnished. This is why Chapter 7 is known as providing a 'fresh start'. At the same time, a person filing for bankruptcy has to surrender all wealth in excess of an exemption level. The exemption level varies across US states, ranging from $\$ 8,000$ in Maryland to unlimited for housing wealth in some states, for example Florida.

The exemption level has two broad categories: housing wealth and non-housing wealth. The former is more important than the latter in most states. The model features liquid wealth and not housing wealth. That would imply that I should use the non-housing related exemption level in the model. However, liquid wealth can be turned into housing wealth in order to benefit from the higher housing related exemption level. ${ }^{3}$ Since this makes it unclear what to use for the model, I do two calibrations: one with a low exemption level of $\$ 10,000$ and another one with a higher exemption level of $\$ 47,800 .{ }^{4}$ One important insight from my paper is that the exemption level plays only a minor role. Using a high or a low exemption level in the benchmark calibration hardly affects the results.

Sometimes it is suggested that the default possibility is unlikely to explain the credit card debt puzzle because households should not rollover their debt for many periods prior to defaulting. Instead they would benefit from repaying their credit card debt during good times and only increase their debt just prior to default. That strategy would avoid the high interest rate payments during good times while keeping the benefit from debt discharge under Chapter 7. This strategy, however, is illegal. Debts above $\$ 1,150$ for unnecessary goods or services or cash advances made within 60 days before filing are nondischargeable. ${ }^{5}$ Moreover, Elias et al. (2001) report that judges sometimes question debts below this threshold so that even smaller cash advances might not be discharged.

An individual can file for Chapter 7 bankruptcy only once every six years. ${ }^{6}$ Under Chapter 13 agents can keep their wealth, debt is not discharged immediately and future earnings are garnished. A person can file for Chapter 13 every six months. Therefore, in the model, agents who default again after already having defaulted under Chapter 7 have to file for Chapter 13.

Table 1 shows some evidence of credit card debt, liquid asset holding, and interest rates from the Survey of Consumer Finances (SCF) in 1998. The population is divided into three groups: the first group in which households borrow on their credit cards more than $\$ 500$ but do not save, one in which households borrow and simultaneously hold low yielding liquid assets (the puzzle group) and another one in which households do not have credit card debt. Since the model abstracts from liquidity issues, I follow Gross and Souleles (2002b) and approximate liquidity needs by one month after tax

\footnotetext{
${ }^{3}$ This is advice given by bankruptcy attorneys, see for example Elias, Renauer, and Leonard (2001).

${ }^{4}$ Both exemption levels are measured in 1993 Dollars. The higher one corresponds to the population weighted median as shown by Mankart and Rodano (2012).

${ }^{5}$ The Bankruptcy Abuse Prevention and Consumer Protection Act (BAPCPA) of 2005 has strengthened these requirements to $\$ 750$ and 90 days.

${ }^{6}$ The data pertain to the period before 2005 when the bankruptcy law was reformed (BAPCPA $2005)$ and this period was increased to 8 years and some form of means testing was introduced.
} 
income. Thus, $12.7 \%$ of households have significant credit card debt and liquid assets in excess of their monthly net income. $66.9 \%$ of households have no significant credit card debt, whereas $20.4 \%$ have debt but liquid assets less than their monthly net income.

TABle 1: CREDit CARD DEBT, Liquid ASSETS AND INTEREST RATES

\begin{tabular}{llccc}
\hline \hline & & Borrow & $\begin{array}{c}\text { Borrow } \\
\text { \& Save }\end{array}$ & Save \\
\hline Fraction of households & & $20.4 \%$ & $12.7 \%$ & $66.9 \%$ \\
\hline Credit card debt & Median & 3,600 & 2,800 & 0 \\
Credit card debt & Mean & 5,714 & 5,036 & 283 \\
\hline Liquid assets & Median & 1,100 & 7,000 & 1,700 \\
Liquid assets & Mean & 1,571 & 11,646 & 10,364 \\
\hline Liquid assets - 1m net income & Median & 0 & 2,750 & 0 \\
Liquid assets - 1m net income & Mean & 0 & 8,141 & 8,061 \\
\hline Interest rate & Median & $15.9 \%$ & $15.0 \%$ & $7.9 \%$ \\
Interest rate & Mean & $14.7 \%$ & $13.7 \%$ & $7.9 \%$ \\
\hline
\end{tabular}

Outstanding debt is highest in the borrower group and somewhat lower in the puzzle group. Liquid asset holding are very low in the borrower only group. While mean asset holdings are similar between the puzzle and the saver group, median holdings are significantly different. The median saver has liquid assets which are less than its net income.

The last two rows show the interest rates which households have to pay on their credit card debt. Here the difference is most striking between the saver and the other two groups. Both interest rates are significantly lower for the former group. Edelberg (2006) documents that credit card companies have become increasingly successful in individualizing interest rates during the 1980s and 1990s. Thus, the last two rows reflect the default probability and expected recovery rates of the credit card companies from which these households borrow. For the saver group the mean and median rates are below $8 \%$ which implies a relatively low default risk. Thus, the default option plays only a minor role for households in this group. They use their credit cards mainly for liquidity purposes.

However, the high interest rates for the puzzle group which are almost as high as for the borrower group reveal that borrowers in this group have a significant default risk. Thus, explaining this group either by time inconsistent preferences or by liquidity needs only without considering default risk seems unwarranted. ${ }^{7}$ More details, in particular the joint density of the puzzle group over debt and assets is shown later in Figure 5(a).

\section{The model}

The model framework is a partial equilibrium overlapping generations model based on Livshits et al. (2007). Each household lives for $J$ periods. Each generation consists of households of measure 1 . Since there is no bequest motive, each household is born

\footnotetext{
${ }^{7}$ Note however, that I define the puzzle group as those with liquid assets in excess of net income. For those with liquid asset below that threshold, the liquidity based explanation by Telyukova and Wright (2008) and Telyukova (2013) is certainly plausible too.
} 
without any wealth and maximizes its own expected lifetime utility. Households face uncertainty with respect to future labor productivity and with respect to small and large wealth shocks, reflecting family risks and health risks.

Financial markets are incomplete, in particular there are no insurance markets in which households could insure against their labor income risks or their health expenditure risks. There are two assets in the economy. First, households can save any non-negative amount by buying a risk-free bond. This bond pays an exogenous interest rate $r^{f}$.

Second, they can borrow non-negative amounts from financial intermediaries. This borrowing is done through notionally non-contingent debt contracts on which households can default however. This default option makes these bonds partially contingent. I abstract from any issues of informational asymmetries. At the point of signing the debt contract, financial intermediaries have the same information set as the households themselves. Therefore, all debt contracts are household specific in that financial intermediaries price these debts according to the characteristics of the specific household.

\subsection{Households}

\subsubsection{Preferences}

Households live for $J$ years. For simplicity I abstract from labor-leisure choice. Households maximize their discounted expected utility of consumption. However, in order to take varying household sizes into account, household size is expressed in terms of equivalence scale units $n_{j}$. Felicity is standard, non-decreasing and concave

$$
U=\sum_{j=1}^{J} \beta^{j-1} u\left(\frac{c_{j}}{n_{j}}\right) .
$$

\subsubsection{Productivity}

Labor productivity of household $i$ at age $j$ is the product of three components: an age specific component $e_{j}$, a household specific persistent component $z_{j}^{i}$, and a household specific transitory component $\eta_{j}^{i}$

$$
y_{j}^{i}=e_{j} z_{j}^{i} \eta_{j}^{i} .
$$

The age specific component $e_{j}$ is chosen to reflect life cycle income patterns that are common across households. The household specific components reflect uncertainties over the life cycle. For example, Storesletten, Telmer, and Yaron (2004) estimate an $\mathrm{AR}(1)$ for log earnings of the following form

$$
\begin{aligned}
& \ln \left(y_{j}^{i}\right)=\ln \left(z_{j}^{i}\right)+\ln \left(\eta_{j}^{i}\right)+\ln g\left(x_{j}^{i}\right) \\
& \ln \left(z_{j}^{i}\right)=\rho \ln \left(z_{j}^{i}\right)+\varepsilon_{j}^{i}
\end{aligned}
$$

where $g(\cdot)$ reflects the deterministic component of earnings. The persistent component $z_{j}^{i}$ follows an AR(1) process with a very high autocorrelation. Storesletten et al. (2004) estimate it to be 0.99 . The variance of the transitory shock is about six times as high as the variance of the persistent shock. The income process is discretized by a Markov chain. 


\subsubsection{Wealth shocks}

In addition to income uncertainty, households also face idiosyncratic wealth shocks. These wealth shocks represent expenditures that have to be incurred due to, for example, a divorce or some necessary medical treatment. It is important to note that these expenditures do not yield any utility, therefore they simply reduce the wealth of the household. If the household does not hold sufficient wealth, he will have to default on these expenditures. These shocks are i.i.d. and uncorrelated with income. It is important to note that these expenditures are due to third parties, e.g. hospitals in the case of a health shock. Thus, if the agent files for bankruptcy, and he does not repay the expenditure shock, it is the hospital that loses money and not the bank. The bank only loses the amount of unsecured credit. ${ }^{8}$

\subsection{Credit market}

There is perfect competition and free entry in the credit market. Therefore, banks make zero expected profit on each contract. The opportunity cost of lending is the safe rate of return on capital which is taken as exogenous.

Households, who have not defaulted in the past, can hold two types of assets: savings $a$ and unsecured debt $d$. Savings earn the household a rate of return $r^{F}$. Unsecured credit incurs a transaction $\operatorname{cost} \tau^{u}$.

Furthermore, I abstract from information asymmetries in the credit market. ${ }^{9}$ Each bank knows the borrower's age $j$ and his persistent component of his labor productivity $z^{i}{ }^{10}$ Therefore, by anticipating the behavior of the borrower, the banks are able to calculate the probability of default and how much they will get in the case of default. Perfect competition implies that they set the interest rate, such that they expect to break even. This interest rate depends on the exemption level $X$ because it affects the incentives to default and the amount the banks recover in this event. The banks offer a menu of one period debt contracts which consist of an amount lent $d$ and a corresponding interest rate to each agent $(j, z)$.

Households who have just defaulted are excluded from borrowing. However, they can still save.

\section{$3.3 \quad$ Timing}

The sequence of events is shown in Figure 1. A household of age $j$ brings forward from last period: a credit record $S$, a value for the persistent component of labor productivity $z_{t-1}$, debt $d$ and savings $a$. At the beginning of the period the expenditure shock $k$ and his labor productivity $z, \eta$ is realized. Since the household can default on the expenditure shock, this expenditure shock is simply added to the household's debt holdings. All households who carry some debt, either because they have borrowed in

\footnotetext{
${ }^{8}$ While this assumption is plausible for health shocks, it is less plausible for e.g. the expenditures for a divorce since households have to pay these costs themselves. One way to model this would be to model the debt contract as a credit card contract with a pre-specified credit line (credit limit) that the household can draw on in case he faces an expenditure shock.

${ }^{9}$ For an analysis of bankruptcy under asymmetric information see Athreya, Tam, and Young (2012)

${ }^{10}$ It is immaterial whether the bank also knows how much the borrower will save. The bank can always anticipate the decision of the borrower.
} 
the previous period and (or) they have been hit by an expenditure shock then decide whether to repay or whether to default. The credit record of a household who had not defaulted in the previous period and who repays this period remains clean. The credit record of a household who defaults in this period is changed to reflect this default. A household who had already defaulted in the previous period will have no debt. If this household is, however, hit by an expense shock, it might default again. This behavior will also be reflected by the credit status.

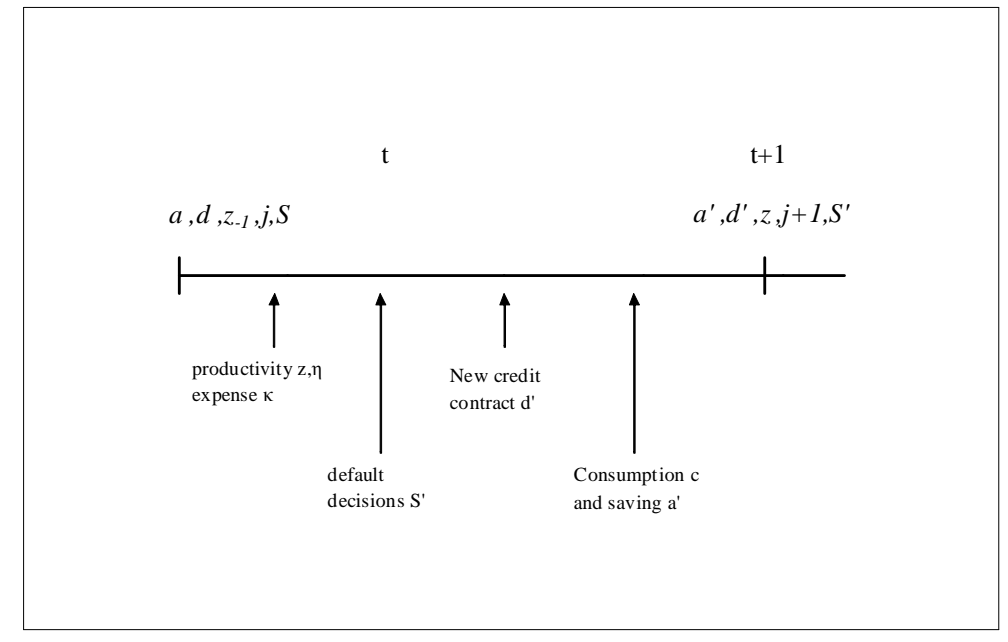

Figure 1: Timing

All households with a clean credit record can borrow $d^{\prime}$ in the unsecured credit market. At the end of the period, each household can decide how much to save $a^{\prime}$ and how much to consume $c$.

\subsection{The household's problem}

The household's problem is defined recursively. The problem is described by three value functions. $V^{R}$ is the value of repaying the debt, $V^{D}$ is the value of defaulting the first time under Chapter 7 , and $V^{D D}$ is the value of defaulting again after the household has already defaulted in the previous period. This last value function is needed since a household can default under Chapter 7 only once every six years.

An unconstrained agent of age $j$ with savings $a$, current productivity $z, \eta$, expense shock realization $\kappa$, and debt $d$ has to decide whether to repay or whether to default.

The value of repaying is given by

$$
\begin{aligned}
V_{j}^{R}(a, d, z, \eta, \kappa) & =\max _{c, a^{\prime}, d^{\prime}}\left\{\begin{array}{c}
u\left(\frac{c}{n_{j}}\right)+ \\
\beta \mathbb{E} \max \left[V_{j+1}^{R}\left(a^{\prime}, d^{\prime}, z^{\prime}, \eta^{\prime}, \kappa^{\prime}\right), V_{j+1}^{D}\left(a^{\prime}, z^{\prime}, \eta^{\prime}\right)\right]
\end{array}\right\} \\
\text { s.t. } c+d+\frac{a^{\prime}}{1+r^{s}}+\kappa & \leq e_{j} z \eta+a+\frac{d^{\prime}}{1+r\left(j, z, d^{\prime}, a^{\prime}\right)}, \\
a^{\prime} & \geq 0, \quad d^{\prime} \geq 0 .
\end{aligned}
$$

where savings $a^{\prime}$ and new debt $d^{\prime}$ have to be non-negative. Since the agent repays, he will be unconstrained tomorrow and therefore has the option to default tomorrow, i.e. 
he can choose the maximum of defaulting or repaying. If the agent's debt repayment and expenditures on the expense shock exceed his income and potential new borrowing, the constraint set is empty, i.e. consumption would have to be negative. In this case the value function is set to negative infinity and the agent will have to default.

The value of defaulting is given by

$$
\begin{aligned}
V_{j}^{D}(a, z, \eta) & =\max _{c, a^{\prime}}\left\{\begin{array}{c}
u\left(\frac{c}{n_{j}}\right)-\Psi+ \\
\beta \mathbb{E} \max \left[V_{j+1}^{R}\left(a^{\prime}, 0, z^{\prime}, \eta^{\prime}, \kappa^{\prime}\right), V_{j+1}^{D D}\left(a, z^{\prime}, \eta^{\prime}, \kappa^{\prime}\right)\right]
\end{array}\right\} \\
\text { s.t. } c+\frac{a^{\prime}}{1+r^{s}} & \leq(1-\gamma) e_{j} z \eta+\min [a, X] \\
a^{\prime} & \geq 0 .
\end{aligned}
$$

Since the household defaults on all unsecured debt $d$ and all expenditures $\kappa$, their values play no role here. However, if the agent defaults, he can keep assets only up to the exemption level $X$. In addition, part of his labor income will be garnished. Even though a household who defaults cannot borrow in the current period, the household can save. This is in contrast to Livshits et al. (2007) who do not allow the agent to save. In their paper, a household is in financial autarky after a default. This assumption has been used by other authors as well because it simplifies the analysis.

However, this financial autarky assumption clearly overstates the punishment from a default since there is no evidence that households who have defaulted in the past are precluded from saving. $\Psi$ is a utility cost of defaulting and reflects both pecuniary costs and non-pecuniary costs. The pecuniary costs, for example court fees and lawyer fees, have been estimated to exceed $\$ 1,000$. In addition $\Psi$ reflects the cost of the stigma of having had to declare bankruptcy. I use this parameter in the calibration to tie down the default rate. If the continuation value of defaulting exceeds the value of repaying, i.e. $V_{j}^{D}(a, z, \eta)>V_{j}^{R}(a, d, z, \eta, \kappa)$, the household will default. This decision is denoted by the indicator function $I_{j}^{D}(a, d, z, \eta, \kappa)$.

In the next period, the household will have no debt but he might be hit by an expense shock. If he is unable to repay the expense shock, he will have to default again. In that case, I assume that he has to surrender all his wealth and part of his income will be garnished. This is in line with Chapter 13 of the U.S. bankruptcy code. Therefore, the value of not repaying expense debt after having already defaulted is

$$
\begin{aligned}
V_{j}^{D D}(a, z, \eta, \kappa) & =u\left(\frac{c}{n_{j}}\right)-\Psi+\beta \mathbb{E} \max \left[\left[V_{j+1}^{R}\left(0, d^{\prime}, z^{\prime}, \eta^{\prime}, \kappa^{\prime}\right), V_{j+1}^{D}\left(0, z^{\prime}, \eta^{\prime}\right)\right]\right. \\
\text { where } c & =(1-\gamma) e_{j} z \eta, \quad d^{\prime}=\left(\kappa-a-\gamma e_{j} z \eta\right)(1+\bar{r})
\end{aligned}
$$

where debt is rolled over to the next period at an exogenous interest rate $\bar{r}$. The decision to default again is denoted by $I_{j}^{D D}(a, z, \eta, \kappa)$.

\subsection{The zero profit condition of the banks}

Since there is perfect competition and free entry in the credit market, the banks make zero profit on each savings contract and on each unsecured loan contract. All agents, except those who default twice, can save at the risk free interest rate $r^{f}$. 
Since I abstract from asymmetric information, banks observe the household fully. This means they know the household's age $j$, cash on hand $e_{j} z \eta+a-d-\kappa$, and persistent component of productivity $z$. In addition, they know how much the household is going to save, i.e. they know $\frac{a^{\prime}}{1+r^{s}}$. Given a savings level $\frac{a^{\prime}}{1+r^{s}}$ and productivity level $z$ the bank knows in which future states of the world the household will be willing to repay and in which the household will default. Therefore, for each amount of unsecured credit $d^{\prime}$, the bank can calculate the default probability $\pi\left(d^{\prime}, a^{\prime}, z, j, \gamma\right)$ and the amount the bank recovers in each default state. This will depend on the exemption level $X$, the fraction of labor income that can be garnished $\gamma^{11}$, and on the amount the household owes in expense debt $\kappa^{\prime}$. I assume that all assets above the exemption level $X$ and the garnished labor income are split proportionally in the repayment of the bank and expense debt. So, the bank receives a fraction $\frac{d^{\prime}}{d^{\prime}+\kappa^{\prime}}$ of labor income $e_{j} z \eta$ and of the savings above the exemption level if these savings exceed the exemption level. In addition, the credit production process incurs real costs $\tau^{u}$ which are assumed to be proportional to the loan size. The zero profit condition is given by

$$
\begin{aligned}
\left(1+r^{f}+\tau^{u}\right) d^{\prime} & = \\
& \left(1-\pi\left(d^{\prime}, a^{\prime}, z, j, \gamma\right)\right)\left(1+r\left(d^{\prime}, a^{\prime}, z, j\right)\right) d^{\prime} \\
& +\pi\left(d^{\prime}, a^{\prime}, z, j, \gamma\right) \mathbb{E}\left(\frac{d^{\prime}}{d^{\prime}+\kappa^{\prime}}\left(\gamma e_{j} z \eta+\max \left[a^{\prime}-X, 0\right]\right)\right) .
\end{aligned}
$$

\subsection{Equilibrium}

Let $(a, d, z, j, S)$ be a state vector for an individual, where $a$ denotes savings, $d$ unsecured borrowing, $z$ the persistent component of labor productivity, $j$, the age of the household, and $S$ the credit status. Let $r^{f}$ be the exogenous interest rate, $\tau^{u}$ the resource costs of producing unsecured credit, $\gamma$ the proportional garnishment, and $X$ the wealth exemption level. A competitive recursive equilibrium is then given by:

- value functions $V_{j}^{R}, V_{j}^{D}, V_{j}^{D D}$ that solve the households problem and lead to optimal policy functions $c, d^{\prime}, a^{\prime}, I^{D}, I^{D D}$,

- an interest rate function that satisfies the zero profit condition,

- and correct default probabilities $\pi\left(d^{\prime}, a^{\prime}, z, j, \gamma\right)=E\left(I_{j}^{D}\left(a^{\prime}, d^{\prime}, z^{\prime}, \eta^{\prime}, \kappa^{\prime}\right)\right)$

\section{Calibration and benchmark results}

In this section, I first show the parametrization. Afterward, I describe the results and compare the model's implications to the data.

\footnotetext{
${ }^{11}$ If there was no garnishment, households would not repay any fraction of the loan. This is not according to the US bankruptcy law which requires bankruptcy filers to have acted in good faith and therefore denies filing for bankruptcy immediately after having taken out a credit.
} 


\subsection{Parametrization}

In order to simplify computations, each model period corresponds to three years. Households are born at age 20, retire with 65 and die at age 74 . This implies that a life in the model has 18 periods, where the last three periods are spent in retirement. As already mentioned, households face no uncertainty in retirement. ${ }^{12}$ In the following, I report only annual values since these are more familiar than triennial values.

The felicity function features constant relative risk aversion $u(c)=\frac{c^{1-\sigma}}{1-\sigma}$, where $\sigma$ is the coefficient of relative risk aversion and set to 2.0. The discount factor is equal to 0.94. The family size life cycle comes from Fernandez-Villaverde and Krueger (2007) which in turn is based on the US Census data for 1990.

The interest rate on saving $r^{f}$ is set to 4.0 percent. This is in line with estimates of the average return to capital in the US. The transaction cost for unsecured credit $\tau^{u}$ is based on Evans and Schmalensee (1999) who estimate that the intermediation cost for credit card debt is 4.0 percent.

Log earnings follow a standard $\mathrm{AR}(1)$ process

$$
\begin{aligned}
& \ln \left(y_{j}^{i}\right)=\ln \left(z_{j}^{i}\right)+\ln \left(\eta_{j}^{i}\right)+\ln g\left(x_{j}^{i}\right) \\
& \ln \left(z_{j}^{i}\right)=\rho \ln \left(z_{j}^{i}\right)+\varepsilon_{j}^{i}
\end{aligned}
$$

where $g(x)$ is the deterministic component. The autocorrelation coefficient $\rho$ is set to 0.99. Its innovation is assumed to be normal, $\varepsilon_{j}^{i} \sim N\left(0, \sigma_{\varepsilon}\right)$, with variance $\sigma_{\varepsilon}^{2}=0.007$. The transitory shock $\eta$ is also assumed to be normal $\eta_{j}^{i} \sim N\left(0, \sigma_{\eta}\right)$ with variance $\sigma_{\eta}^{2}=0.043$. All these annual values are mapped into triennial values and then discretized into a Markov process with five states. The transition matrix $\Pi\left(z^{\prime} \mid z\right)$ is assumed to be age-independent. The transitory shock is discretized using three states where ten percent of the population receive a positive shock and ten percent a negative shock.

Upon entering retirement, there are no further shocks. In order to make retirement income (social security) dependent on earnings, it has two components: first a lump-sum component equal to $35 \%$ of average earnings and then an individual specific component consisting of 30 percent of the last earning.

The expense shock $\kappa$ can take three values $\left\{0, \kappa_{1}, \kappa_{2}\right\}$. The first value means no shock. The small shock, $\kappa_{1}$, is set to $\$ 10,973$ annually and has probability $\pi_{1}=2.368$ percent. Livshits et al. (2007) aggregate three different shocks of similar size. First, a divorce shock which has probability 1.244 percent which leads to expenditures on the divorce and a loss in economies of scale. Second, an unwanted pregnancy which occurs with 0.5 percent. Lastly, medical shocks that are not too big and which affect 0.625 percent of households each year. The big shock $\kappa_{2}$ is purely a large medical expense shock. This is set to $\$ 34,154$ annually and has probability $\pi_{2}=0.153$ percent. This means that a small fraction of households are hit by very large medical expenditure shocks.

\footnotetext{
${ }^{12}$ This assumption is innocuous for income uncertainty since retirees receive social security benefits. It is less plausible for expense shocks. But I maintain it for computational simplicity. Since old people do not borrow much and hardly ever default in the data, this assumption is unlikely to bias the results.
} 
TABle 2: The FIXED PARAMETERS

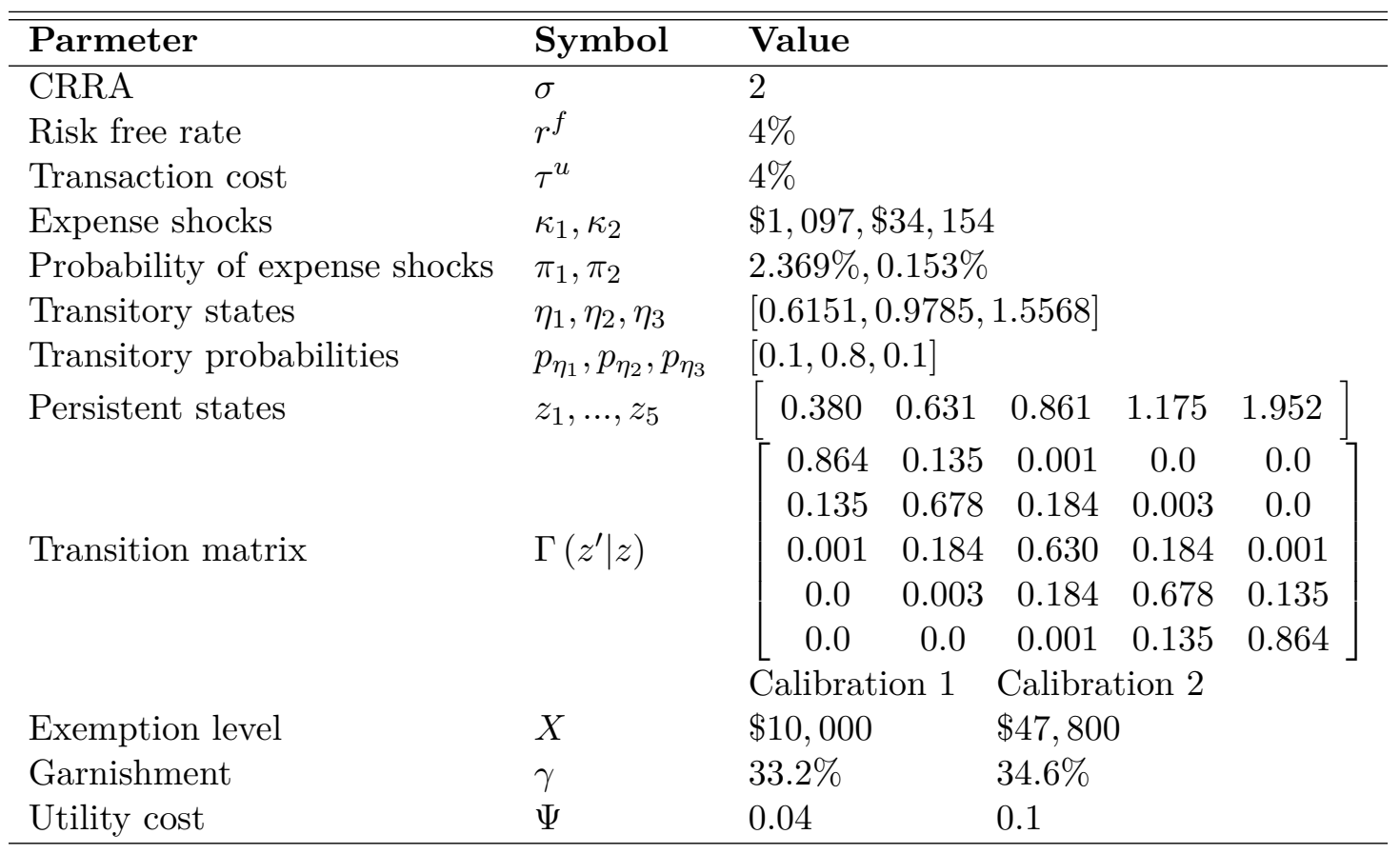

As explained in section 2, wealth exemption levels differ across U.S. states. Therefore, I present two calibrations of the model: one with a low exemption level of $\$ 10,000$ and one with a higher exemption level of $\$ 47,800$.

The remaining parameters to be set are the utility cost of bankruptcy $\Psi$ and the garnishment parameter $\gamma$. Livshits et al. (2007) do not include the utility cost in their model. They calibrate $\gamma$ in order to match the observed debt to earnings ratio of 8.4 percent. The default rate is then endogenously determined in their model. Their model does very well and manages to explain 85 percent of observed chapter 7 defaults.

However, this result is not robust. My model nests their model as a special case. In particular if I set the exemption level to zero, the model replicates their results. But if I set the exemption level to a plausible one, the model produces too many defaults. This shows that ignoring the wealth exemption level as is done in many previous papers leads to biased results. I calibrate $\Psi$ to match the observed default rate of 0.84 percent. All the parameters are shown in Table 2.

As can be seen in Table 3, both calibrations match the targeted moments very well. The bankruptcy target is the percentage of all non-business related Chapter 7 bankruptcies, averaged between 1995-1999.

TABle 3: The TARGEts

\begin{tabular}{llll}
\hline \hline Target & Data & Calib 1 & Calib 2 \\
\hline Debt to earnings ratio & $8.4 \%$ & $8.39 \%$ & $8.39 \%$ \\
Chapter 7 bankruptcies & $0.84 \%$ & $0.84 \%$ & $0.85 \%$ \\
\hline
\end{tabular}




\subsection{Benchmark model}

In this subsection, I first present some implications of the model. ${ }^{13}$ Then, I will discuss some policy functions. Lastly, I will show some life cycle implications of the model.

\subsubsection{Model implications}

In order to assess the model, I present some further comparisons between the model and the data in Table 4. The first important result is that the model can explain the extensive margin of the credit card debt puzzle. The fraction of borrowers who save is very close to the number reported in Gross and Souleles (2002a). They show that one third of credit card borrowers hold simultaneously low yielding liquid assets in excess of one month income.

TABle 4: Model implications

\begin{tabular}{llll}
\hline \hline Variable & Data & Calib 1 & Calib 2 \\
\hline Fraction borrowers who save & $33 \%$ & $25.3 \%$ & $34.2 \%$ \\
Average borrowing rate & $11.2 \%$ & $10.9 \%$ & $10.3 \%$ \\
Relative earning of defaulters & $49.1 \%$ & $53.9 \%$ & $52.9 \%$ \\
Average debt to income ratio of defaulters & $187 \%$ & $238.8 \%$ & $229.0 \%$ \\
Recovery probability & $2.4 \%$ & $4.7 \%$ & $1.42 \%$ \\
\hline
\end{tabular}

The average interest rate is similar to the average interest rate the Federal Reserve Board reports on two-year personal loans. The earnings of defaulters are about $50 \%$ below the average earnings in the model and in the data. The amount of debt households hold at the time of filing for bankruptcy is a bit too high in the model compared to the data. However, the numbers from Sullivan et al. (2000) are based on a relatively small sample of bankruptcy cases.

The Executive Office for United States Trustees (2001) reports that lenders recover part of their debt only in about $2.4 \%$ of consumer bankruptcy cases. ${ }^{14}$ This very low recovery probability is also an outcome in the model. The recovery probability is above $2.4 \%$ in the low exemption calibration, whereas it is below in the high exemption calibration. This happens because higher savings are needed to exceed the exemption level in the latter case.

\subsubsection{Pricing and policy functions}

In this subsection, I first show how the possibility to save affects the price and availability of credit. Then, I show examples of policy functions of the household and a first look at the credit card debt puzzle.

\footnotetext{
${ }^{13}$ The results shown here are for calibration 1 (the low exemption level). Results for calibration 2 are very similar and therefore relegated to the appendix.

${ }^{14}$ The Executive Office for United States Trustees (2001) reports the annual number of Chapter 7 bankruptcies between 1994 - 2000 and the number of cases in which the debtor had assets above the exemption level. The annual average over this period is 3.6\%. The General Accounting Office (1994) reports that a disproportionally large fraction, one third of the these asset cases resulted from business bankruptcies.
} 


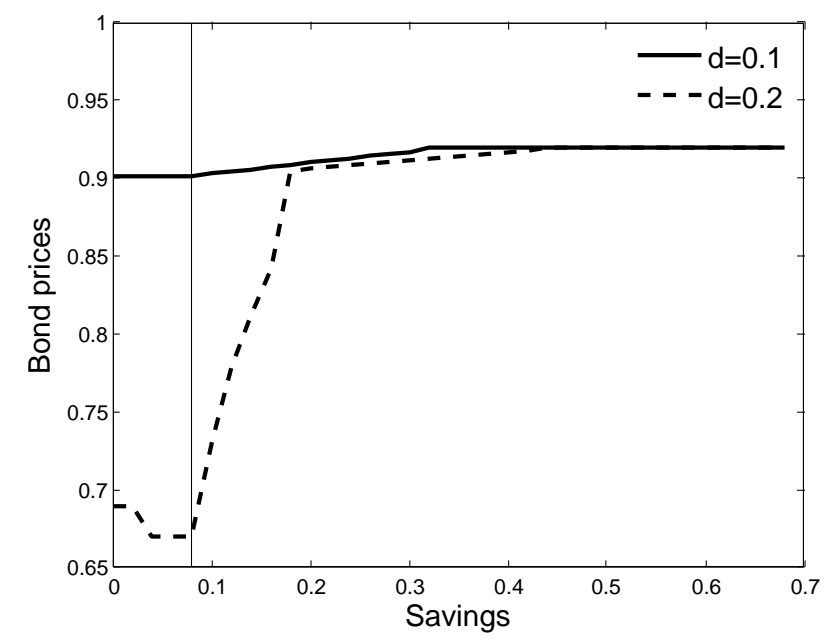

Figure 2: Prices for loAns of Size $d=0.1$ AND $d=0.2$ FOR Different LeVEls OF SAVINGS

The prices at which households can borrow depend on their default incentives. The more households borrow the higher is the incentive to default and therefore the lower is the price of the bond. In addition, the incentive to default also depends on the exemption level. There are two opposing effects at play. On the one hand, the more a household has saved, the higher is its repayment ability. On the other hand, for savings up to the exemption level, the more the household has saved, keeping the repayment requirement constant, the better off the household will be in default. This leads to a non-monotonic pricing schedule.

Figure 2 shows the price of bonds with repayment requirement $d=0.1$ and $d=0.2$ respectively, for different levels of savings of agents with low labor productivity. If the household has no savings, it will default in some states. This is more likely when the household borrows more. This is the reason that the prices for borrowing $d=0.2$ are always below of those borrowing only $d=0.1$. If savings are positive but below the exemption level, the household is better off defaulting, therefore, the bond price falls. In this case banks will recover nothing in case of a default. Once savings exceed the exemption level, banks recover part of the loan because assets in excess of the exemption level go to the bank. This is reflected in an increase in the price of the bond. Since the household loses all its assets above the exemption level, default becomes costlier. This lowers the incentive to default. If the household has saved a lot, he will actually never default and therefore he will be able to borrow at the risk free rate.

Figure 2 also shows that these incentives depend on the amount borrowed. If repayment requirements are high, as is the case when the household borrows $d=0.2$, then the default incentive is already high without any savings. An increase in savings increases the default incentive further. And, similar to the case of borrowing only $d=0.1$, once the household saves more than the exemption level, the recovery rate of the bank increases and therefore the loan price increases. It is important to note that these pricing functions pertain to particular bonds and agents might or might not choose an element of this particular pricing function. Equilibrium choices are shown in Figure 3. 

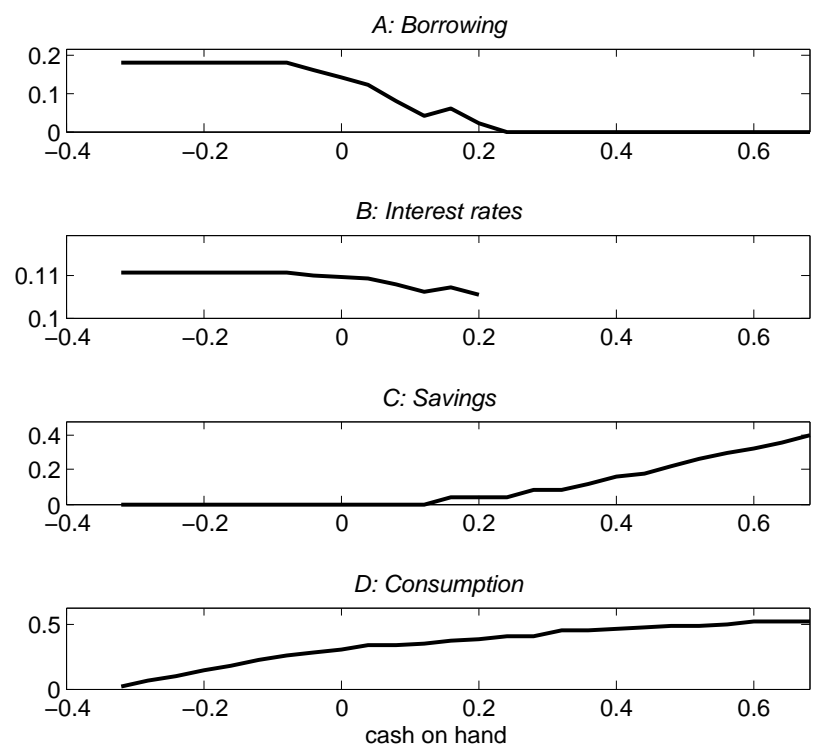

Figure 3: Policy functions of An Agent Aged 26 AND With Low PERsistent LABOR PRODUCTIVITY

Figure 3 shows several policy functions of households aged 26, who have a low persistent labor productivity and who have not defaulted in the previous period. All panels have the cash on hand of the agent after the current shocks were realized, production has taken place and previous debt (or assets) has been repaid on the x-axis. Panel $A$ shows the amount they borrow. Panel $B$ shows the (annual) interest rate they have to pay on these loans. Panel $C$ shows their savings decision. Recall that they save at the constant risk-free interest rate. Panel $D$ shows their consumption decision.

Poor agents, those with cash on hand of less than -0.075 do not borrow more than 0.18. Since they will default when they receive a bad shock, they have to pay a higher interest rate. These agents prefer not to save since their marginal utility of consuming immediately is so high. Agents with cash on hand of more than -0.075 start borrowing less. Therefore the interest rate declines.

The most interesting agents are those with cash on hand between 0.12 and 0.20 . These agents borrow at an (annual) interest rate around $10.5 \%$ and save at the lower rate of $4 \%$ simultaneously, i.e. these agents give rise to the credit card debt puzzle. They do this because they can default on the unsecured debt in bad states. Agents with cash on hand around 0.25 are actually net savers. Nevertheless, they are willing to pay this high interest rate on their debt because of the insurance offered by its partial contingency. If they default, they can keep all of their savings since these are below the exemption level. Agents with cash on hand above 0.20 do not borrow. Therefore, the interest rate in panel $B$ is not shown. These agents only save at the risk-free rate. The last two cases already show that the puzzle households hold relatively few assets, i.e. conditional on being borrower, savings are relatively small. The intensive margin of the credit card debt puzzle is small which will be discussed in more detail in section 4.3. 


\subsubsection{Life cycle implications}

Income and consumption of the model have the observed hump over the life cycle. In this subsection, I show the fraction of borrowers, the amount borrowed, and the interest rates over the life cycle. Since the key contribution of the paper is to introduce two assets into a life cycle model, I show how these variables differ across agents who either only borrow or who borrow and save simultaneously. The left column of Figure 4 shows households who only borrow. The right column shows households who borrow and save, i.e. the puzzle households.
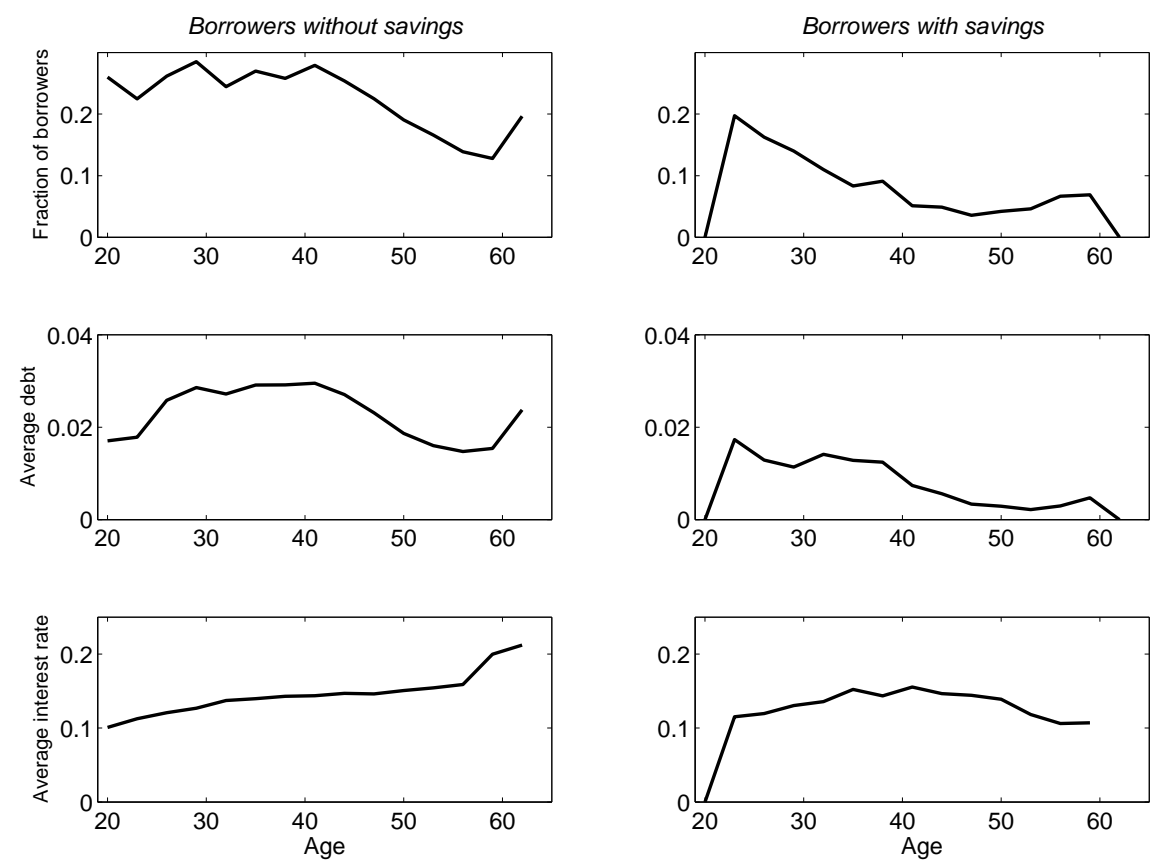

\section{Figure 4: Fraction of Borrowers, AVERAGe DEBT and interest Rates of BORROWERS WHO DO NOT SAVE AND OF BORROWERS WHO SAVE}

The first row of Figure 4 shows that the fraction of agents who only borrow is higher across all age groups. The second row shows that these households borrow substantially more than households who borrow and save. Both these quantities show a hump-shape with an increase at the end of the working lives.

In Figure 3, we saw that the very poor agents are the ones who only borrow. They do this because their current marginal utility of consumption is so high that they prefer not to save at all. Since these agents are also likely to default, they have to pay higher interest rates, as can be seen in the last row of Figure 4. The incentive to default of these agents rises almost monotonically over their life cycle. The main reason for this is that there is less time left and therefore the punishment of being excluded from the unsecured credit market has a declining impact. This is particularly apparent in the last period in which agents can default. The second row shows an increase in borrowers at age 62 , and in particular an increase in the amount they borrow. This higher level of borrowing combined with no further concern for the future, because there is no 
uncertainty after 65 , explains the sharp increase in interest rates in the last periods of life.

The interest rates of borrowers who also save is lower, even though conditional on the loan size, they have a higher incentive to default. But as we have seen in Figure 3, agents who borrow and save are relatively richer than those who only borrow. Their default incentives are relatively constant over their life cycle, therefore the interest rate at which they can borrow does not change much.

\subsection{Credit card debt puzzle}

Table 4 has already shown that the model matches the extensive margin of the credit card debt puzzle well. One third of households who borrow at high interest rates simultaneously save at low interest rates. Figure 5 shows the intensive margin of the puzzle, i.e. the joint density of household debt and savings in the data and in the model. The data are from the Survey of Consumer Finances in 1998. Since assets in the model are liquid, I use the liquid asset category in the SCF. Unsecured debt is proxied by credit card debt. ${ }^{15}$

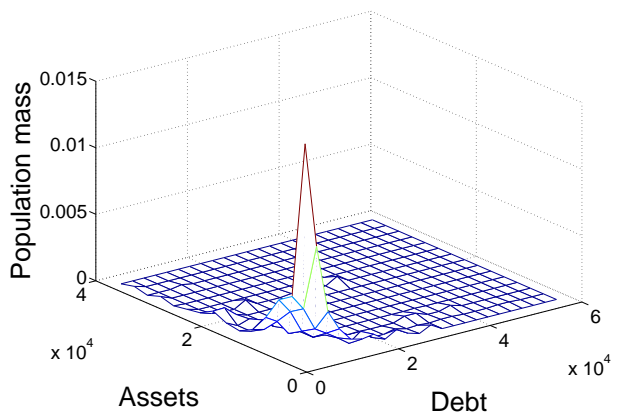

(a) Data

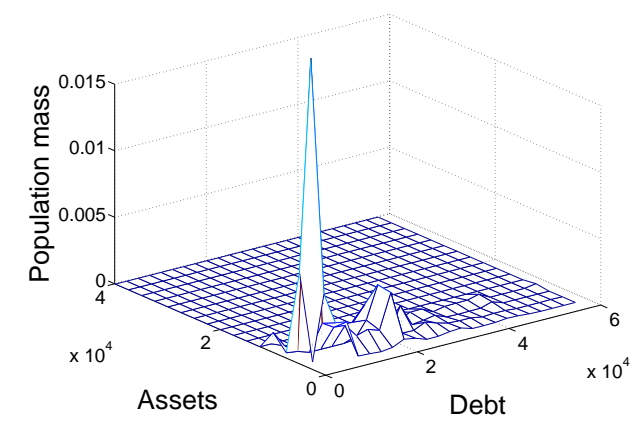

(b) Model

Figure 5: Debt PortFolios

The model matches also the intensive margin of the credit card debt puzzle reasonably well. Most households are close to the origin, meaning their debt and their savings are rather small. The small intensive margin of the credit card debt puzzle can be understood with the help of Figure 3. The puzzle households are those with net wealth around zero. They borrow and save relatively small amounts. While the model gets the bulk of the households right, there are two differences to the data. First, in the data there are few borrowers who hold liquid assets of more than $U S \$ 15,000$ whilst this is not true in the model. The median (mean) asset holdings are $\$ 6,182(\$ 5,281)$ in the model and $\$ 7,000(\$ 11,646)$ in the data, see also Table 1. Second, there are more savers whose debt exceeds $\$ 10,000$ in the model than in the data. The median (mean) debt holdings of the puzzle households in the model are $\$ 2,492(\$ 9,909)$. The corresponding numbers in the data are $\$ 2,800(\$ 5,036)$.

\footnotetext{
${ }^{15}$ Following Gross and Souleles (2002b), I compute credit card debt as the debt that is in excess of one month income. Credit card debt below this threshold might be due to liquidity considerations which are not in the model.
} 


\section{Changes in the exemption level}

In this section, I present the implications of varying the exemption level from zero to high levels. In particular, I will investigate the following exemption levels: The lowest level is $X=0$, the case implicitly analyzed by Livshits et al. (2007) because they do not have an exemption level in their model. ${ }^{16}$ A low level $X=0.063$ which corresponds to the observed minimum of $\$ 8,000$ found in Maryland. The benchmark value of $X=0.08$ corresponds to $\$ 10,000$. A high level $X=1$ which corresponds to about $\$ 124,700$. I will report the maximum of almost $\$ 250,000$ found in Kansas only occasionally since these results are usually the same as the once obtained for $X=1$.

\subsection{Default rates}

Since the incentive to default increases with the exemption level, default should be positively correlated with the exemption level. ${ }^{17}$ However, as shown in Figure 6 there is no positive relationship between the exemption level and the occurrence of default. The model yields a small positive non-linear relationship. ${ }^{18}$

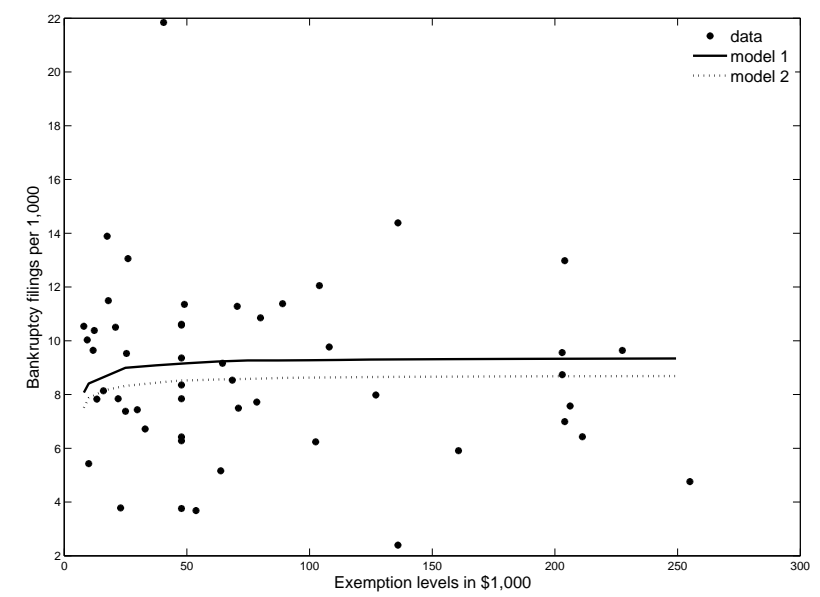

Figure 6: BANKRUPtCy RATES FOR DIFFERENT EXEMPTION LEVELS

Previous models, for example Athreya (2008), Pavan (2008) and Lopes (2008) for consumers and Mankart and Rodano (2012) for entrepreneurs, find a strong positive relationship between the exemption level and default rates. The reason my model predicts only modest increases in the default rate when the exemption is very low and almost no increase once it exceeds $\$ 20,000$ is that almost no household is affected by

\footnotetext{
${ }^{16}$ Since I do not recalibrate the model for each exemption level, the results that I report for $X=0$ and their results differ. However, these differences are very small since the value of my calibrated variables are very close to the values in their calibration.

${ }^{17}$ This is unless credit rationing is so severe that the most risky borrowers are excluded from the market completely. In this case the selection effect might overturn the positive relationship between the exemption level and the default rate.

${ }^{18} \mathrm{~A}$ regression of the data shows that a positive coefficient cannot be excluded. In particular, the correlation found by the model is within the 95 percent confidence interval.
} 
such high exemption levels. Almost all households that default have assets below the exemption level, as shown by the very small recovery probabilities in Table 4 . The non-linear effect at low exemption levels indicates that not including the exemption level might lead to spurious results.

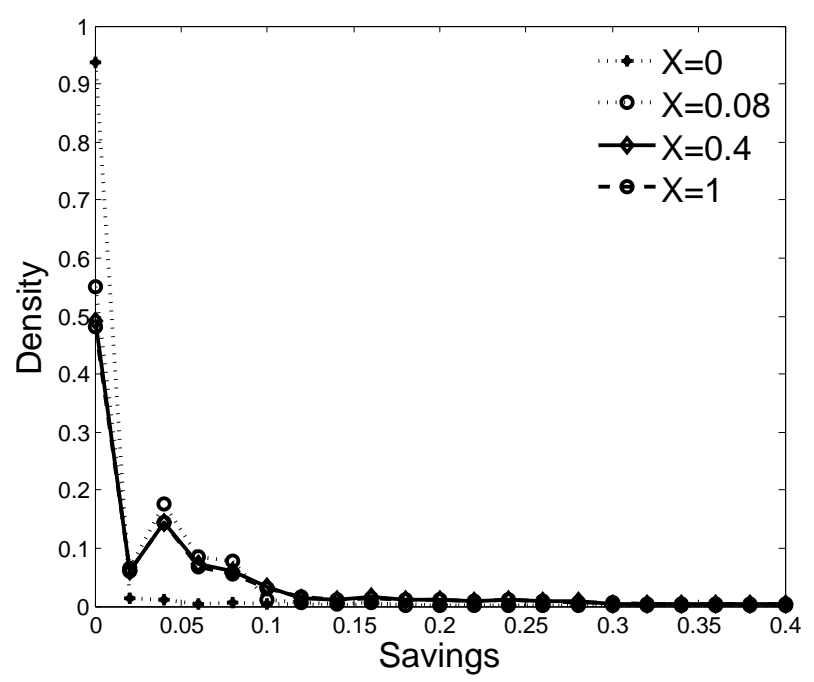

Figure 7: Distribution of ASSETS OF DEFAUlters FOR DifFERENT EXEMPtion LEVELS

Not only are recovery probabilities below $5 \%$, but also recovery rates are small. Figure 7 shows the after shock asset distribution of defaulters for different exemption levels. The effect of increases in the exemption level fade out quickly. If the exemption level is zero, less than six percent of households have positive savings. Thus, in very few cases are lenders able to recover any assets at all. If the exemption level is increased to a still low level of 0.08 , the distribution shifts outwards. This means agents hold 
more wealth at the moment of default. The reason for this is that being able to keep some wealth leads agents who might default to increase their savings since they can keep it now. Further increasing the exemption level to $X=0.4$ alters the distribution somewhat. But an increase to $X=1$ has almost no additional effect. However, fewer and fewer households have assets above the exemption level. Thus, even in states with a very small exemption levels, almost no defaulter will have any assets above that exemption level.

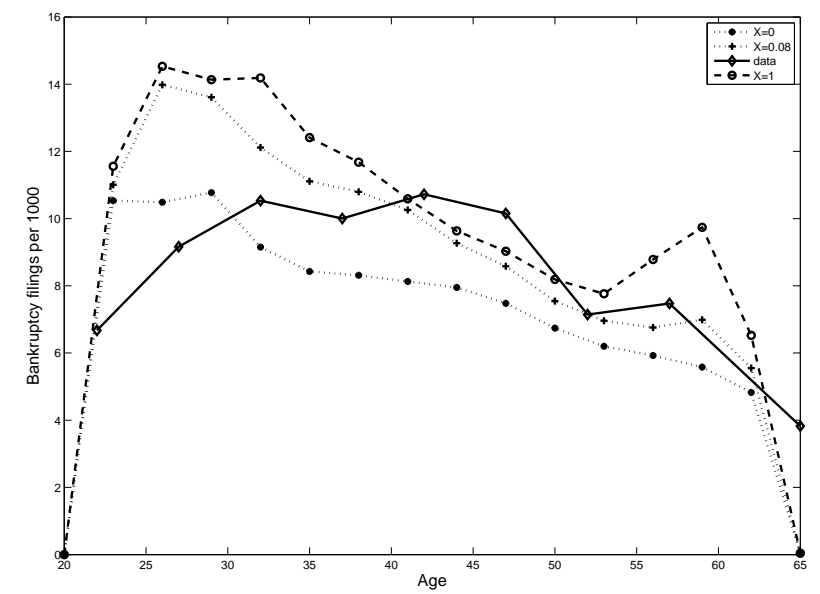

Figure 8: Defaults over the Life CyCle: Data, Benchmark Model $(X=0.08)$, LOW EXEMPTION $(X=0)$ AND High EXEMPTION $(X=1)$

In addition to looking at average default rates, it is instructive to look at default rates over the life cycle. Figure 8 shows default rates for three different exemption levels and the default rates observed in the data. ${ }^{19}$ While the benchmark model gets the hump-shape over the life cycle right, the peak in the default rate occurs too early compared to the data. In addition, defaults pick up at the end of the life in the model. ${ }^{20}$

The main result that increases in the exemption level beyond an intermediate level does not lead to an increase in bankruptcies can also be seen in Figure 8. The case of a high exemption level $X=1$ is very similar to the benchmark case $X=0.08$. Default rates are only marginally higher during the last periods of life.

\subsection{Debt, savings and welfare}

Figure 9 shows aggregate savings and aggregate borrowing for exemption levels, ranging from 0 to 2 which corresponds to $\$ 0$ to $\$ 250,000$. Borrowing increases rapidly for low exemption levels before it falls back to a smaller level. And then, it remains unchanged for exemption levels higher than $X=0.2$.

Savings however keep on increasing for all levels of the wealth exemption, even though the increases get smaller. Nevertheless, it is almost the only variable that keeps

\footnotetext{
${ }^{19}$ For observed bankruptcies, I used the data from Sullivan et al. (2000) and adjusted the mean.

${ }^{20}$ The model produces this marked increase because everyone retires for sure at 65 and I assume that there is no further uncertainty. If the model included heterogeneity with respect to retirement age and additional uncertainty this peak would flatten out.
} 

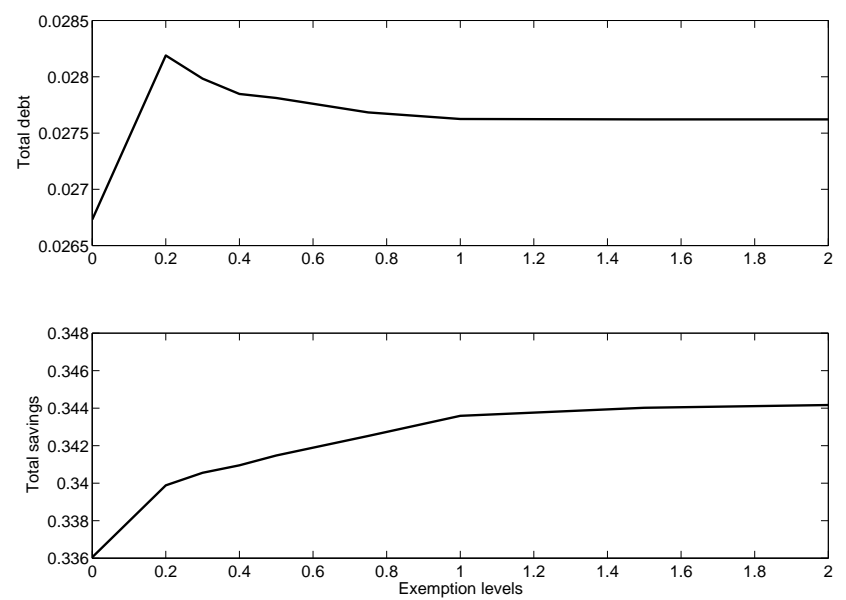

Figure 9: Debts AND SAVINGS FOR DIFFERENT EXEMPtion LEVELS.

changing even for high exemption levels. The reason is that the insurance through a high exemption level now is available also for relatively richer households. This leads these households to increase their savings supply.

The top panel in Figure 10 shows the welfare impacts of changing the exemption level. As utilitarian welfare measure, I use the percent increase in lifetime consumption necessary to make the households equally well off under both regimes (ECV). $X=0.08$ is the benchmark case. A negative number here means that this particular exemption level is worse than the benchmark and vice versa. The bottom panel shows the variance of $\log$ consumption. A lower variance means that consumption is more equally distributed, which from an ex ante perspective makes households better off.

Figure 10 shows that there are welfare gains from moving from a very low level of the exemption $(X=0)$ to an intermediate level $(X=0.3)$. The bottom panel shows that these welfare gains are obtained by decreasing the variance of log consumption, i.e. by distributing consumption more equally. Thus, a positive exemption level allows for more risk-sharing in this economy. The welfare gains from further increases are extremely small.

Livshits et al. (2007) compare a US style system in which debt is wiped out upon default (fresh start) with a European style system where this is not the case. They find that the fresh start system is better by about $0.06 \%$ in terms of ECV. Incorporating the second important feature of the US system, a positive exemption level, doubles this welfare differences.

The net supply of savings, aggregate savings minus aggregate debt in Figure 9, is increasing in this model. While the model is a partial equilibrium model, this, at least, suggests that general equilibrium effects are unlikely to overturn the case for high exemption levels.

Figure 10 shows that the welfare differences between positive exemption levels are very small despite the significant differences in exemption levels across US states. In fact, these findings are suggestive since otherwise, at least if the political process were efficient, a convergence of exemption levels should have occurred over the last decades. 

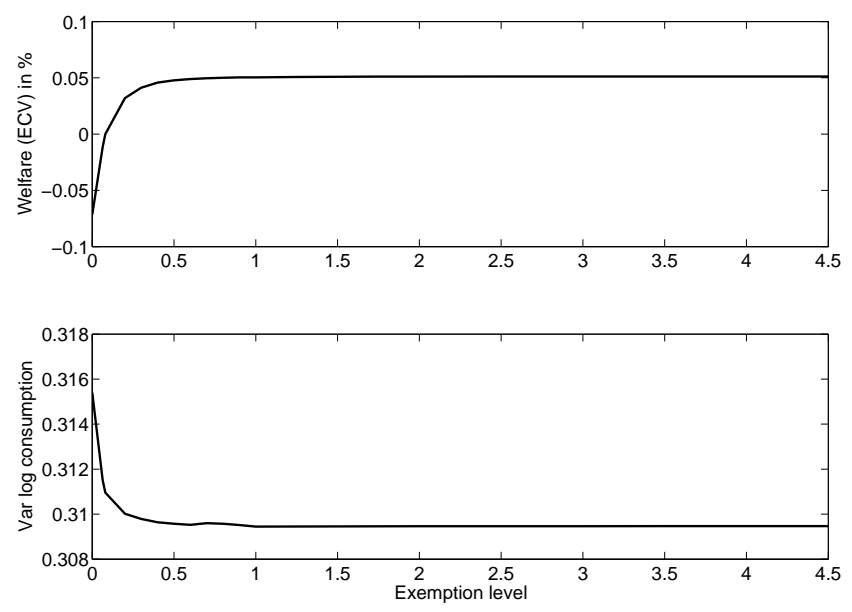

Figure 10: Welfare AND VARIANCE OF LOG CONSUMPTION FOR DIFFERENT EXEMPTION LEVELS.

Moreover, Figure 6 shows that the model implies, consistent with the data, only small differences in bankruptcy rates for different exemption levels.

\subsection{Default reasons}

Table 5: Default by Reason for $\mathrm{X}=0$ and $\mathrm{X}=0.08$

\begin{tabular}{lcccr}
\hline \hline \multirow{2}{*}{ A: Exemption $\mathbf{X = 0}$} & \multicolumn{3}{c}{ Expense shock } & \\
\cline { 2 - 4 } & Low & High & None & Total \\
\hline No income fall & $63.8 \%$ & $9.8 \%$ & $1.0 \%$ & $75.6 \%$ \\
Fall in persistent income only & $8.4 \%$ & $1.5 \%$ & $5.2 \%$ & $15.1 \%$ \\
Fall in transitory income only & $7.3 \%$ & $1.1 \%$ & $0.1 \%$ & $8.5 \%$ \\
Both fall & $1.0 \%$ & $0.2 \%$ & $0.6 \%$ & $1.8 \%$ \\
\hline Total & $80.5 \%$ & $12.6 \%$ & $6.9 \%$ & $100.0 \%$ \\
\hline \hline \multirow{2}{*}{ B: Exemption $\mathbf{X}=\mathbf{0 . 0 8}$} & \multicolumn{4}{c}{ Expense shock } \\
\cline { 2 - 4 } & Low & High & None & Total \\
\hline No income fall & $56.2 \%$ & $8.4 \%$ & $2.0 \%$ & $66.6 \%$ \\
Fall in persistent income only & $7.7 \%$ & $1.3 \%$ & $13.7 \%$ & $22.7 \%$ \\
Fall in transitory income only & $6.7 \%$ & $0.9 \%$ & $0.3 \%$ & $7.9 \%$ \\
Both fall & $0.9 \%$ & $0.1 \%$ & $1.6 \%$ & $2.6 \%$ \\
\hline Total & $71.5 \%$ & $10.7 \%$ & $17.6 \%$ & $100.0 \%$ \\
\hline \hline
\end{tabular}

Households in the model are exposed to three types of uncertainty: expense (wealth) shocks, changes in persistent labor productivity, and transitory income shocks. In this section, I compare the default reasons across two exemption levels: the Livshits et al. (2007) case of $X=0$ and the benchmark of $X=0.08$.

The biggest difference between the two panels in Table 5 is that the fraction of defaulters who have experienced no wealth shock more than doubles from $6.9 \%$ to 
$17.6 \%$ when the exemption level is increased from $X=0$ to $X=0.08$. In particular, households who have experienced no wealth shock but whose persistent productivity has dropped compared to the previous period increases from $4.9 \%$ to $11.7 \%$. In the data, the fraction of defaulters who report job reasons is at least as high as those reporting expense shocks. Thus, the benchmark model with a positive exemption level probably still overstates the role of expense shocks. But it is a significant improvement over a model without any exemption. Further increases in the exemption level (not shown) do not lead to any significant changes in the default reasons.

\section{Conclusion}

This paper develops a heterogeneous agent life cycle model in which agents are subject to three types of shocks: persistent and transitory labor productivity shocks and expense shocks. Financial markets in the model are incomplete but agents can insure themselves against the risk by holding a portfolio of unsecured debt and savings. I show that including the possibility to keep some of the assets, i.e. a positive wealth exemption level, as is the case in all U.S. states, is important.

The model can explain the credit card debt puzzle. Around one third of borrowers who borrow at high rates simultaneously save at low rates. But they borrow and save only relatively modest amounts. The model also shows that ignoring positive exemption levels biases the results. However, the exact value of the exemption level is unimportant because almost no defaulting household has assets in access of the exemption level. This is already true for a small exemption level.

One limitation of the model is that it features only liquid assets and not also illiquid assets / debt, like housing and mortgages. Having all four in a model would certainly help to match the life cycle profiles of net worth better. Another fruitful area for future research is to examine all three explanations for the credit card debt puzzle: default possibility as here, self control problems and liquidity needs within one model and to test which one is most important. However, it might well be that all three of them matter. Liquidity needs are most plausible for small asset holdings, self control problems probably affect households to different degrees. The default option is most likely to matter for significant households with significant asset holdings.

\section{Appendix}

\subsection{Computational algorithm}

In this section, I present an overview of the computational algorithm. As is standard in the literature, I solve this program by backward induction. I assume that the household faces no uncertainty in the last period of his life and cannot default. I discretize the asset space, the persistent state of productivity, the temporary productivity, and the expense shock.

\section{Algorithm 1 1. Solve the value functions for the last period T.}

2. Given the values in $T, I$ solve the households problems in $T-1$. Since agents are not allowed to default in period $T$, this is simple. 
3. In period $T-2$, I set up a grid of savings values $a^{\prime}$ and borrowing values $d^{\prime}$. These two grids form a matrix.

(a) Then, I calculate the default probabilities and associated recoveries for each entry of this matrix and each level or persistent productivity by using the continuation values in period $T-1$ by looping over persistent and transitory productivity and the expense shock. These default probabilities imply an interest rate for each pair of values $a^{\prime}, d^{\prime}, z$.

(b) Given this array, I solve for the optimal decision of the households. Since households who have defaulted cannot borrow, calculating their value functions is standard.

4. I continue to do that until the first period

5. I simulate the model for 10 million households.

\subsection{Results for calibration 2}

In the main section results were shown for the low exemption level calibration. The corresponding results of the high exemption level calibration are shown in this appendix.

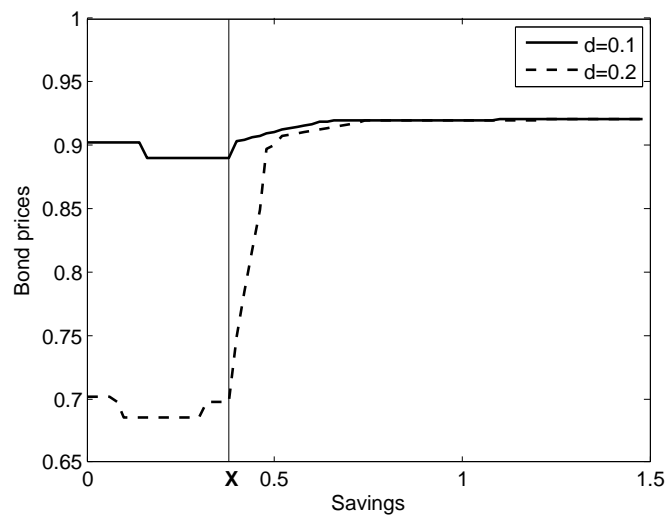

Figure 11: Bond PRICES FOR LOANS OF SIZE $d=0.1$ AND $d=0.2$ FOR DIFFERENT LEVELS OF SAVINGS; LOW EXEMPTION CALIBRATION

The pricing function, Figure 11, in the low exemption case is very similar to the high exemption case, see Figure 2. Since the exemption level is higher, bond prices start increasing at a higher savings level too.

The equilibrium policy functions are also very similar. Those agents who borrow and save simultaneously save at most 0.04 which is still below the now lower exemption level.

The life cycle profiles of the fraction of borrowers who save and who do not save are shown in Figure 13. The only difference to the low exemption case, see Figure 4, is that the average debt of those who do save peaks later in the life cycle. The differences are small however.

Figure 14 shows the life cycle profile of defaults for different exemption levels, based on the high exemption calibration. Since the benchmark exemption level now is higher, 

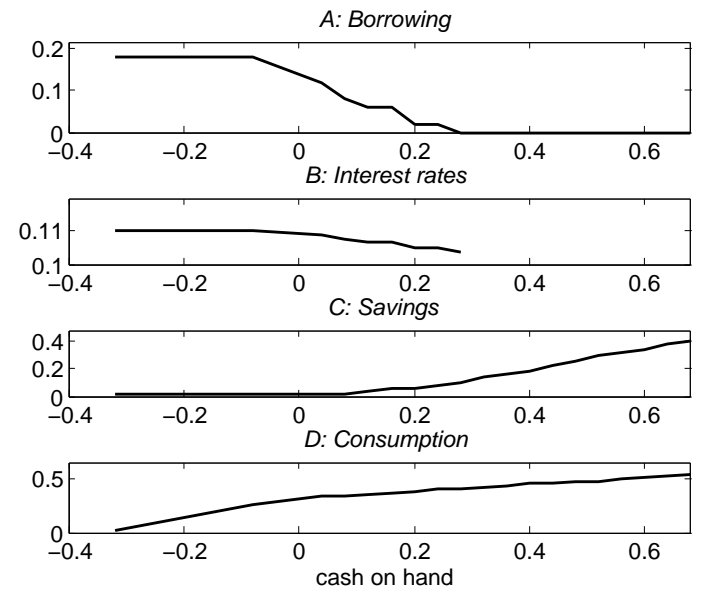

Figure 12: Policy functions of An Agent Aged 26 And With Low PERsistent LABOR PRODUCTIVITY; LOW EXEMPTION CALIBRATION
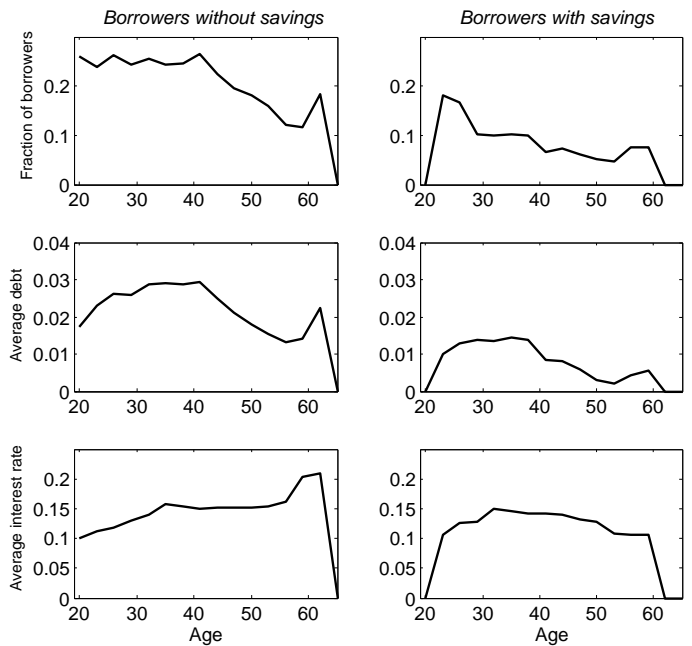

Figure 13: Fraction of Borrowers, AVERAge DEBT AND INTEREST RATES OF BORROWERS WHO DO NOT SAVE AND OF BORROWERS WHO SAVE; LOW EXEMPTION CALIBRATION 
there is still almost no difference when the exemption level is increased from $X=0.38$ to $X=1.0$. This confirms the argument that ignoring exemption level completely is not warranted even though the effects of higher exemption levels vanish quickly. Compared to Figure 8, the default rate now peaks somewhat earlier in life.

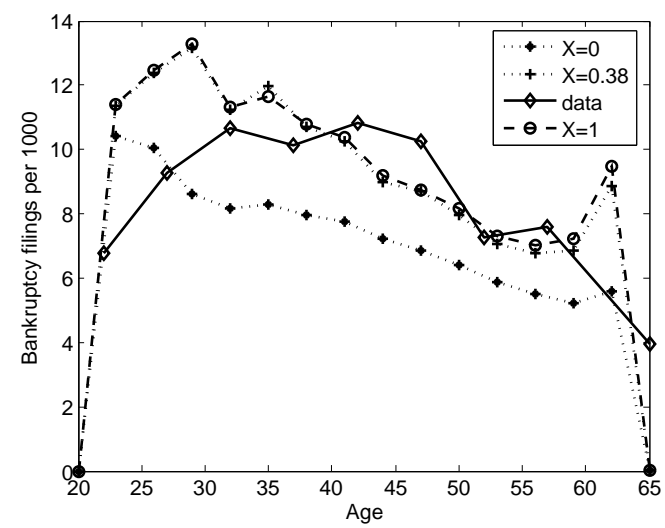

Figure 14: Defaults over the life Cycle: Data, Benchmark Model $(X=0.38)$, LOW EXEMPTION $(X=0)$ AND HIGH EXEMPTION $(X=1)$; LOW EXEMPTION CALIBRATION

Default reasons for the low exemption calibration are shown in Table 6. The results are, once more, very similar to the high exemption calibration.

Table 6: Default by Reason for $\mathrm{X}=0$ and $\mathrm{X}=0.08$; low exemption CALIBRATION

\begin{tabular}{lcccr}
\hline \hline \multirow{2}{*}{ A: Exemption $\mathbf{X = 0}$} & \multicolumn{3}{c}{ Expense shock } & \\
\cline { 2 - 4 } & Low & High & None & Total \\
\hline No income fall & $63.8 \%$ & $10.2 \%$ & $1.0 \%$ & $75.1 \%$ \\
Fall in persistent income only & $8.1 \%$ & $1.6 \%$ & $4.9 \%$ & $14.6 \%$ \\
Fall in transitory income only & $7.3 \%$ & $1.2 \%$ & $0.2 \%$ & $8.7 \%$ \\
Both fall & $0.9 \%$ & $0.2 \%$ & $0.6 \%$ & $1.7 \%$ \\
\hline Total & $80.2 \%$ & $13.2 \%$ & $6.6 \%$ & $100.0 \%$ \\
\hline \hline \multirow{2}{*}{ B: Exemption $\mathbf{X = 0 . 3 8}$} & \multicolumn{4}{c}{ Expense shock } \\
\cline { 2 - 4 } & Low & High & None & Total \\
\hline No income fall & $55.1 \%$ & $8.8 \%$ & $2.3 \%$ & $66.1 \%$ \\
Fall in persistent income only & $8.6 \%$ & $1.4 \%$ & $11.7 \%$ & $21.7 \%$ \\
Fall in transitory income only & $7.4 \%$ & $1.1 \%$ & $0.9 \%$ & $9.4 \%$ \\
Both fall & $1.3 \%$ & $0.2 \%$ & $1.3 \%$ & $2.8 \%$ \\
\hline Total & $72.4 \%$ & $11.4 \%$ & $16.2 \%$ & $100.0 \%$ \\
\hline \hline
\end{tabular}

Figure 15 shows the population mass of households who simultaneously borrow and save. The total fraction of households who hold such a portfolio is $8.8 \%$ in the low exemption calibration. This is slightly lower than in the high exemption calibration where this fraction is $9.24 \%$. The reason is that a lower exemption level makes saving for richer borrowers less attractive.

Figure 16 shows the asset distribution of defaulters. It is almost identical to Figure 


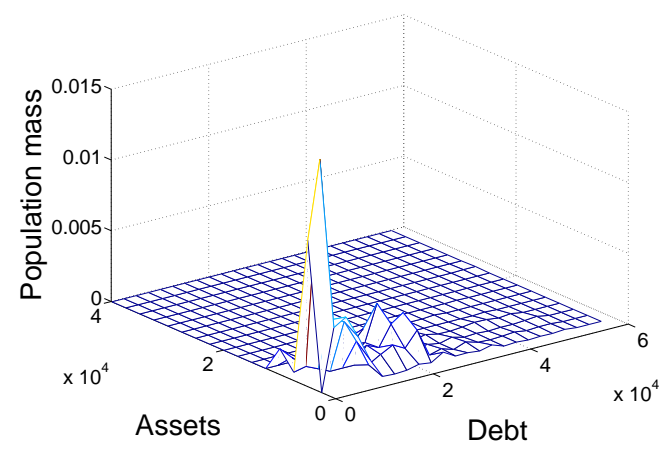

Figure 15: Debt Portfolios

7. This confirms the result that high exemption level hardly matter since there are very few agents who simultaneously hold assets when they default.

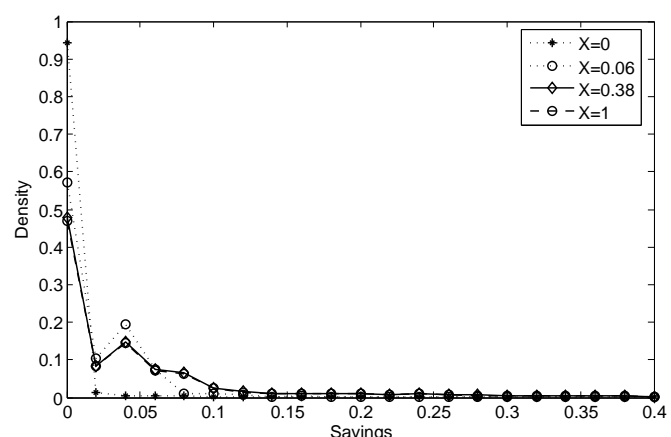

Figure 16: Distribution of ASSETS OF DEFAUlters FOR DifFERENT EXEMPTION LEVELS; LOW EXEMPTION CALIBRATION

Aggregate results for debt and savings, see Figures 17 and 18, are very similar to the high exemption calibration results, see Figures 9 and 10. 

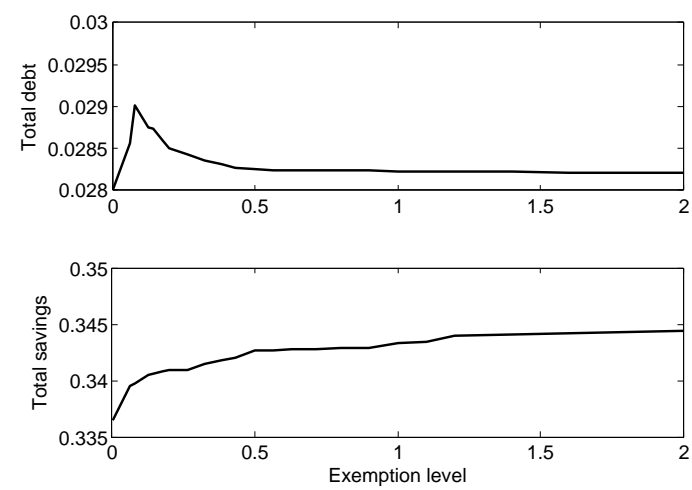

Figure 17: DebTS AND SAVINGS FOR DIFFERENT EXEMPTION LEVELS; LOW EXEMPTION CALIBRATION
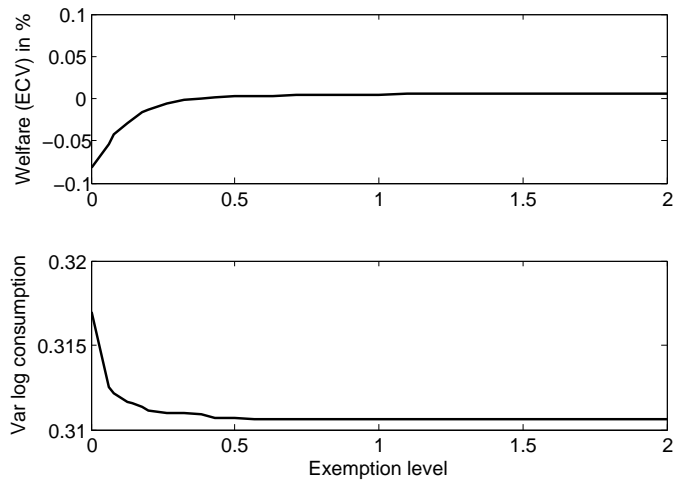

FigURE 18: WELFARE AND VARIANCE OF LOG CONSUMPTION FOR DIFFERENT EXEMPTION LEVELS; LOW EXEMPTION CALIBRATION 


\section{References}

Athreya, K. (2006). Fresh start or head start? Uniform bankruptcy exemptions and welfare. Journal of Economic Dynamics and Control 30(11), 2051-2079.

Athreya, K. (2008). Default, insurance, and debt over the life-cycle. Journal of Monetary Economics 55(4), 752-774.

Athreya, K., X. S. Tam, and E. R. Young (2012). A quantitative theory of information and unsecured credit. American Economic Journal-Macroeconomics 4(3), 153.

Bertaut, C. C., M. Haliassos, and M. Reiter (2009). Credit card debt puzzles and debt revolvers for self control*. Review of Finance 13(4), 657-692.

Chatterjee, S., D. Corbae, M. Nakajima, and J.-V. Rios-Rull (2007). A quantitative theory of unsecured consumer credit with risk of default. Econometrica 75(6), $1525-1589$.

Dubey, P., J. Geanakoplos, and M. Shubik (2005). Default and punishment in general equilibrium. Econometrica 73(1), 1-37.

Edelberg, W. (2006). Risk-based pricing of interest rates for consumer loans. Journal of Monetary Economics 53(8), 2283-2298.

Elias, S., A. Renauer, and R. Leonard (2001). How to file for Chapter 7 Bankruptcy (9 ed.). Nolo.

Evans, D. and R. Schmalensee (1999). Paying with plastic: the digital revolution in buying and borrowing. The MIT Press.

Executive Office for United States Trustees (2001, June). United States trustee program: preliminary report on Chapter \%.

Fay, S., E. Hurst, and M. J. White (2002). The household bankruptcy decision. The American Economic Review 92(3), 706-718.

Fernandez-Villaverde, J. and D. Krueger (2007). Consumption over the life cycle: Facts from consumer expenditure survey data. The Review of Economics and Statistics $89(3), 552-565$.

General Accounting Office (1994, July). Bankruptcy administration: case receipts paid to creditors and professionals. Report to the chairman, subcommittee on economic and commercial law, committee on the judiciary, House of Representatives. United States General Accounting Office General Government Division.

Gross, D. and N. Souleles (2002a). An empirical analysis of personal bankruptcy and delinquency. Review of Financial Studies 15(1), 319.

Gross, D. and N. Souleles (2002b). Do Liquidity Constraints and Interest Rates Matter for Consumer Behavior? Evidence from Credit Card Data. Quarterly Journal of Economics 117(1), 149-185.

Hintermaier, T. and W. Koeniger (2011, April). Debt portfolios. CEPR Discussion papers 8359, 53. mimeo. 
Lefgren, L. and F. McIntyre (2009). Explaining the Puzzle of Cross-State Differences in Bankruptcy Rates. J. Law 83 Econ. 52, 367-779.

Li, W. and P.-D. Sarte (2006). U.S. consumer bankruptcy choice: The importance of general equilibrium effects. Journal of Monetary Economics 53(3), 613-631.

Livshits, I., J. MacGee, and M. Tertilt (2007). Consumer bankruptcy: A fresh start. American Economic Review 97(1), 402-418.

Lopes, P. (2008). Credit card debt and default over the life cycle. Journal of Money, Credit and Banking 40(4), 769-790.

Mankart, J. and G. Rodano (2012). Bankruptcy law, debt portfolios, and entrepreneurship. Technical report, University of St. Gallen, School of Economics and Political Science.

Pavan, M. (2008). Consumer durables and risky borrowing: The effects of bankruptcy protection. Journal of Monetary Economics 55(8), 1441-1456.

Storesletten, K., C. Telmer, and A. Yaron (2004). Consumption and risk sharing over the life cycle. Journal of Monetary Economics 51(3), 609-633.

Sullivan, T., E. Warren, and J. Westbrook (2000). The fragile middle class: Americans in debt. Yale Univ Pr.

Telyukova, I. A. (2013). Household need for liquidity and the credit card debt puzzle. The Review of Economic Studies 80(3), 1148-1177.

Telyukova, I. A. and R. Wright (2008). A model of money and credit, with application to the credit card debt puzzle. The Review of Economic Studies 75(2), 629-647. 